\title{
AN EXPLORATION OF THE FACTORS AFFECTING Users' Satisfaction With Mobile Payments
}

\author{
Lisa Y. Chen and Wan-Ning Wu \\ Department of Information Management, I-Shou University, Taiwan
}

\begin{abstract}
Mobile payment allows consumers to make more flexible payments through convenient mobile devices. While mobile payment is easy and time save, the operation and security of mobile payment must ensure that the payment is fast, convenient, reliable and safety in order to increase the users' satisfaction. Therefore, this study based on technology acceptance model to explore the impact of external variables through perceived usefulness and perceived ease of use on users' satisfaction. The data analysis methods used in this study are descriptive statistical analysis, reliability and validity analysis, Pearson correlation analysis and regression analysis to verify the hypotheses. The results show that all hypotheses are supported. However, mobile payment is still subject to many restrictions on development and there are limited related researches. The results of this study provided insight into the factors that affect the users' satisfaction for mobile payment. Related services development of mobile payment and future research suggestions are also offered.
\end{abstract}

\section{KEYWORDS}

Mobile Payment, Technology Acceptance Model, Users’ satisfaction

\section{INTRODUCTION}

In recent years, many businesses in the industry have invested in the development of the mobile payment market. For the sake of consumers' convenience, using mobile devices to pay for products and services not only eliminates traditionally cumbersome payment methods but also enables consumers to make payment anytime anywhere [1] [2]. In addition, it spares consumers the trouble of carrying wallets and credit cards and saves them both time and effort [3].

Mobile devices allow consumers to quickly browse various kinds of catalogues without any temporal or spatial restrictions. The convenience of mobile payment mechanism not only improves the efficiency of consumer shopping but also makes shopping quicker and easier [4]. It can also fulfil environmentally-friendly paperless policy and enhance the effectiveness of corporate control costs. Mobile payment is different from traditional payment. Modern consumers demand transaction speed, convenience and security in their payment mechanism [5]. For this reason, the development of mobile payment must take into account the characteristics of mobile payments.

Ondrus and Pigneur [6] believe that mobile payments must be personalized, mobile and facilitate participants' mutual communication through wireless communication technology. Where payment is required, the mobile devices equipped with mobile payment mechanism are the vehicles of payment. In addition, mobile payment is not subject to temporal or spatial restrictions and allows products and services to be purchased anytime anywhere in the actual or virtual world. Researchers believe that although mobile payment has the potential to completely change traditional methods by which consumers pay for products and services, whether mobile payment 
can become the standard payment service and whether it is compatible with App services are questions that remain to be answered and overcome [7].

While the number of mobile App users in Taiwan is rapidly growing, the imperfection of mobile payment mechanism and back-end infrastructure still raise consumers' concerns about security. In order to boost consumers' trust in mobile payment and ensure their security and convenience, the usage method and payment process development of mobile payment must meet customers' potential needs and enhance their willingness to use mobile payment. This study uses a technology acceptance model to examine the effects that external variables, convenience, compatibility and trust have on consumers' perception of the usefulness and easiness of mobile payment in order to understand the level of consumers' satisfaction with mobile payment.

\section{LITERATURE REVIEW}

\subsection{Mobile Payment}

Mobile payment development has allowed consumers to make payment from their mobile devices anytime anywhere without being restricted by time or place [8]. This flexible payment method has given consumers considerable convenience. Mobile payment means the act of payment via a smartphone or mobile device. Scholars have defined mobile payment as a mobile payment mechanism that uses a traditional or new payment system to enable the safe transfer of funds in a financial transaction from an organization or an individual to any other party [9] [10]. Scholars Dahlberg et al. [11] have defined the concept of mobile payment as a way for consumers to pay for goods, services or accounts using a mobile device such as a mobile phone, smartphone or PDA. Mobile devices can be used to pay different services and products including ringtones, trademarks, news, music and online games as well as various actual entities such as tickets, parking fees, transportation fees and online bills.

Mobile payment methods are divisible into account payment, credit card payment, token payment and telecommunications bill payment. When using the account payment method, the consumer and merchant each has a bank account. When the consumer requests to make a payment, the system service provider contacts bank where the consumer has his or her account, confirms whether the account in question belongs to the consumer, and checks whether there is sufficient money in the account to trade. If there is sufficient money to carry out the transaction, the transaction money is transferred into the merchant's account [5].

Credit card payment is a method where the consumer makes a payment using his or her credit card. At the time of payment, the consumer enters his or her credit card number and verification code. After the transaction has been successfully authorized, the processing bank pays the amount of the transaction to the merchant. Token payment is divisible into prepaid-mode and accountmode [7]. For prepaid-mode such as stored value cards, the consumer must purchase the amount before trading. Account-mode token payment involves linking to a bank account or credit card and uses the deposit or credit in the account to buy tokens to trade. Telecommunication bill payment involves the consumer adding the amount of the transaction to a telecommunication bill after a transaction is made and the telecommunication carrier transferring that money to the merchant [12].

Mobile payment is different from general electronic payment and must have the following characteristics: 1 . When payment is required, the mobile device is used as the primary payment instrument. 2. Wireless communication technology is used by participants to send messages. 3. It is not subject to time or space and can take place anytime anywhere. 4. It can be used to buy products in the actual or virtual world. 5. It has the characteristics of personalization and action 
[13]. Mobile payment is divisible into remote payment and adjacent payment. Remote payments are online payments, such as paying with a credit card online or with an App or electronic wallet. Payments that must be done with a business entity face to face such as QR Code and NFC mobile phone credit card are adjacent payments. Despite the convenience and time-saving elements of paying via mobile devices, security concerns have deterred many consumers [14].

Also, issues such as prevalence among other businesses, whether there is user stability, and whether the system can be supported into the future, are some major challenges that operators face. For this reason, security is an important consideration for payment trading systems. In addition, online shopping is different from general transaction in that consumers do not have physical access to the products. In the online shopping process, the convenience of website system operations, personal information, security and privacy can all affect consumers' confidence in online shopping. Thus, businesses must establish a secure network environment to enhance consumers' confidence in online shopping.

\subsection{TeChNOLOGY ACCEPTANCE ModeL}

Davis [15] has proposed the concept of a technology acceptance model (TAM). It is mainly used to predict users' acceptance of information systems and understand the motives and likely problems facing users of the system. TAM extends the theory of reasoned action (TRA) proposed by researchers Fishbein and Ajzen [16] discussed factors that influence satisfaction and behaviour intention. TAM proposed that satisfaction depends on an individual's behaviour intention, while an individual's behaviour intention is influenced by attitude, perception, behaviour control and cognitive factors. Thus, Davis [15]combines the original concept with TRA and proposes a TAM (as shown in Figure 1) targeting the characteristics of the information system, believing that the user's perception of usefulness and user-friendliness is affected by external variables, while actual use is affected by behaviour intention. Behaviour intention is determined by the attitude of using a technology, while attitude is influenced by the perception of usefulness and easiness [17].

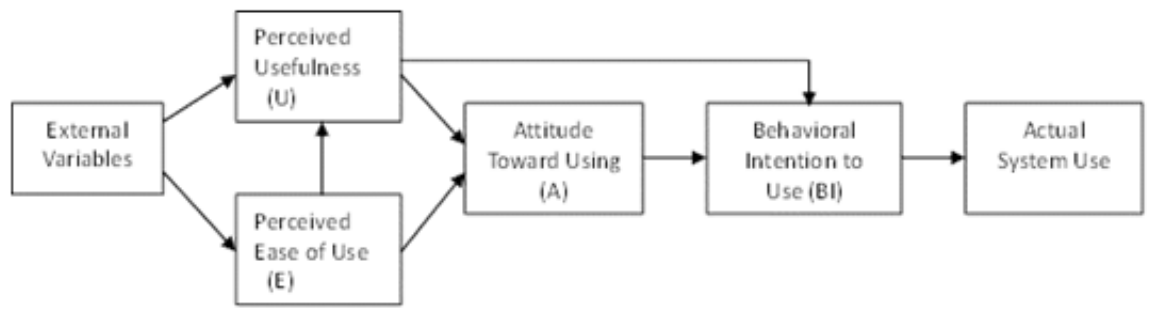

Figure 1.The original technology acceptance model [15]

Many researchers [18] [19] [20] have applied TAM to different information systems and technologies, and found that the user's perception of knowledge and perceived ease of use really affect their acceptance of information technology. In order to improve the ability of the model to predict and explain users' behaviour, many empirical studies have incorporated the technology acceptance model into external variables to gain a better understanding of the factors that affect the usefulness and ease of use for potential users.

TAM argues that external variables can affect users' behaviour. Brown [21] believes that the convenience of a product or service can raise the consumer's awareness of the product or service and help improve the consumer's willingness to use and purchase it. Yoon and Kim [22] believe that the convenience of an action technology can positively affect the perception of usefulness. 
The more users feel the temporal and spatial convenience of a product or service, the more readily they continue to use it. Convenience is the consumers' feeling that the process of consumption can save them shopping time and energy. It can make them accept a product or service and increase their willingness to consume. Rogers [23] argues that compatibility is the degree of consistency between the users' perception of the existing value of an innovative system and their past experience and demands. Therefore, the value brought about the innovation and technology must enable the recipient to feel a level of consistency between the value system, their past experience and their potential needs. On the contrary, if a new information technology fails to make users feel the value compatibility, it is very difficult for them to accept this new information technology [24].

Kim and Tadisina [25] believe that the privacy of personal data and the security of data transmission affect the degree of consumer confidence in online stores. Even though mobile devices can allow consumers to shop anytime anywhere, security issues are the main obstacles to mobile shopping and the biggest issue affecting consumers' trust [26]. Because trust is the consumer's understanding of an online provider's ability to provide service and goodwill, the security of the network environment provided by the industry can enhance consumers' confidence in online stores and heighten their satisfaction [27] [28].

\section{RESEARCH METHOD}

Technology acceptance model has been widely discussed and adopted by domestic and international researchers in the field of information system to explain and predict users' acceptance of a new information system. Therefore, this study uses technology acceptance model as a theoretical basis to examine the factors that affect users' satisfaction with mobile payment.

\subsection{RESEARCH MODEL, HYPOTHESES, AND OPERATIONAL DEFINITION}

Based on the research motivation and purpose, this study integrates the analyses in the relevant literature and proposes a research model (as shown in Figure. 2), deducing hypotheses, and operational definition (as shown in Table 1).

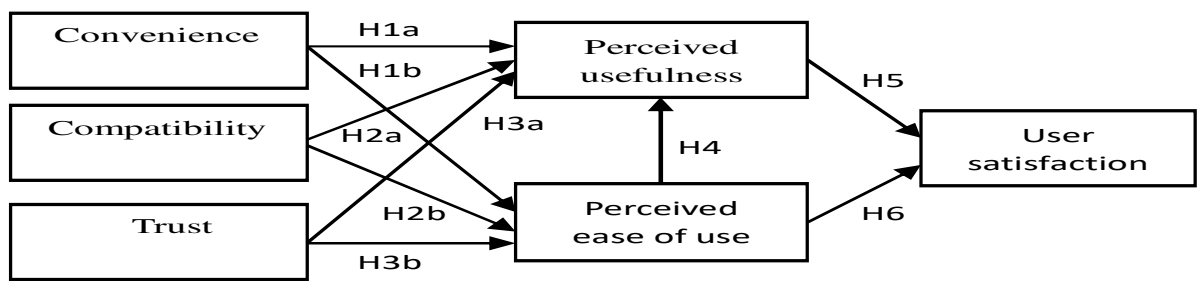

Figure 2.The research model

This study hypothesizes as follows; it mainly discusses the relationship between convenience, compatibility, trust, perceived usefulness, ease of use and users' satisfaction of mobile payment:

H1a: Convenience will have a significant impact on perceived usefulness.

H1a: Convenience will have a significant impact on perceived usefulness.

H1b: Convenience will have a significant impact on perceived ease of use.

H2a: Compatibility will have a significant impact on perceived usefulness.

$\mathrm{H} 2 \mathrm{~b}$ : Compatibility will have a significant impact on perceived ease of use.

H3a: Trust will have a significant impact on perceived usefulness.

H3b: Trust will have a significant impact on perceived ease of use.

H4: Perceived ease of use will have a significant impact on perceived usefulness. 
H5: Perceived usefulness will have a significant impact on user satisfaction.

H6: Perceived ease of use will have a significant impact on user satisfaction

This study has examined the relevant literature and discussions by domestic and international experts and compiled the following definition for the different variables as shown in sentence.

Table 1. The operational definition

\begin{tabular}{|c|l|c|}
\hline Variables & \multicolumn{1}{|c|}{ Operational Definition } & Sources \\
\hline Convenience & $\begin{array}{l}\text { Convenience means consumers' belief that } \\
\text { using mobile payment services can save } \\
\text { them time and effort }\end{array}$ & [22] [23] \\
\hline Compatibility & $\begin{array}{l}\text { Compatibility means the degree of } \\
\text { consistency that consumers feel mobile } \\
\text { payment can meet their needs and lifestyle. }\end{array}$ & [24] [25] \\
\hline Trust & $\begin{array}{l}\text { Trust means the degree of trust that } \\
\text { consumers feel when using mobile } \\
\text { payment. }\end{array}$ & [25] [27] \\
\hline $\begin{array}{c}\text { Perceived } \\
\text { Usefulness }\end{array}$ & $\begin{array}{l}\text { Perceived usefulness means the degree of } \\
\text { usefulness that consumers perceive about } \\
\text { using mobile payment to pay for } \\
\text { transactions. }\end{array}$ & [16] [18] \\
\hline [21]
\end{tabular}

\subsection{Measures}

This study uses a questionnaire survey method and reviews the relevant literatures to work out the measurable questions between the variables. It follows experts' and scholars' recommendations and corrects the ambiguous language and repetitive content to ensure that the questionnaire content is complete, appropriate and offers a precise measurement of the variables. Once the questionnaire design has been completed, the questionnaire will be distributed and the data collected. The data collected from the questionnaire will be assessed and quantified. Each variable is measured by multiple items on a five-point Likert scale, dividing from "Strongly Disagree," "Disagree," "Neutral," "Agree," and "Strongly Agree," each of which is designated by scores from 1 to 5 respectively. Finally, the results will be summarized, and conclusions and related proposals presented.

\section{RESEARCH METHOD}

This study uses SPSS statistical software to analyse and assess the effective 127 random samples. It conducts a factor analysis to extract the factors, and uses a maximum rotation method to rotate the factors, and analyses the factor loading of each question and assesses the suitability of the samples [29]. The reliability and validity of the questionnaire are calculated using Cronbach's coefficient. Based on the hypothesis, the analysis was carried out by descriptive statistical 
analysis, reliability and validity analysis, and the reliability of the questionnaire is analysed in accordance to factor analysis, Pearson's correlation coefficient analysis and regression analysis.

\subsection{Results Of Analysis}

This study focuses on the relevance that external variables, convenience, compatibility, privacy, security, perceived usability and perceived ease of use has on the satisfaction of consumers using mobile payments. Table 1 shows the background characteristics of respondents. The sample was 51 percent male and 49 percent female, with the majority of respondents holding undergraduate degrees. Most of the respondents (46.4\%) had used mobile payment for online shopping, and over 68 percent of respondents were between the ages of 25 and 30.

Based on the results of pre-test, the KMO value was 0.789 and the Bartlett's test of sphericity chisquared value was 1433.600; $\mathrm{P}<0.001$. While the test results $\mathrm{KMO}$ value is greater than 0.6 and $\mathrm{P}$ $<0.001$, represents significant and the sample data is very suitable for factor analysis. For the reliability analysis, Nunnally [29] has indicated 0.7 to be an acceptable reliability coefficient, the results of this study have all reliability coefficients more than 0.856 . In addition, the Pearson correlations of the two-tailed test analysis are shown in Table 2, convenience, compatibility, safety and privacy, perceived usability, perceived ease of use and satisfaction were found to be significant level $(\mathrm{P}<0.01)$.

Table 2. Pearson correlations

\begin{tabular}{|l|c|c|c|c|c|c|}
\hline & $C$ & $C P$ & $T$ & PU & PEOU & US \\
\hline Convenience (C) & 1.000 & & & & & \\
\hline Compatibility (CP) & $0.393^{* *}$ & 1.000 & & & & \\
\hline Trust (T) & $0.399^{* *}$ & $0.818^{* *}$ & 1.000 & & & \\
\hline Perceived Usefulness (PU) & $0.327^{* *}$ & $0.582^{* *}$ & $0.740^{* *}$ & 1.000 & & \\
\hline Perceived ease of use (PEOU) & $0.343^{* *}$ & $0.408^{* *}$ & $0.516^{* *}$ & $0.460^{* *}$ & 1.000 & \\
\hline User Satisfaction (US) & $0.838^{* *}$ & $0.557^{* *}$ & $0.470^{*}$ & $0.382^{* *}$ & $0.375^{* *}$ & 1.000 \\
\hline
\end{tabular}

For $\mathrm{H} 1 \mathrm{a}$ and $\mathrm{H} 1 \mathrm{~b}$, the results of regression analysis showed that $\mathrm{D}-\mathrm{W}$ statistic were 1.965 and 1.978 with a VIF of 1.000 ranging between 1.5 2.5, which implies no autocorrelation. For H1a, the determination coefficients showed that $\mathrm{R} 2=0.107$, Adj-R2 $=0.100, \mathrm{~F}=14.999$, and $\beta=0.327$ $(\mathrm{P}=0.00<0.001)$. For $\mathrm{H} 1 \mathrm{~b}$, the determination coefficients showed that $\mathrm{R} 2=0.118$, Adj- $\mathrm{R} 2=0.111$, $\mathrm{F}=16.824$, and $\beta=0.343(\mathrm{P}=0.00<0.001)$. H1a and $\mathrm{H} 1 \mathrm{~b}$ reached a significance level. For $\mathrm{H} 2 \mathrm{a}$ and $\mathrm{H} 2 \mathrm{~b}$, the results showed that, $\mathrm{D}-\mathrm{W}=2.296$ and 1.977 . For $\mathrm{H} 2 \mathrm{a}$, the determination coefficients showed that $\mathrm{R} 2=0.339$, Adj-R2 $=0.334, \mathrm{~F}=64.112$, and $\beta=0.582(\mathrm{P}=0.00<0.001)$. For $\mathrm{H} 2 \mathrm{~b}$, the determination coefficients showed that $\mathrm{R} 2=0.166$, Adj-R2 $=0.160, \mathrm{~F}=25.126$, and $\beta=0.408$ $(\mathrm{P}=0.00<0.001) . \mathrm{H} 2 \mathrm{a}$ and $\mathrm{H} 2 \mathrm{~b}$ reached a significance level.

For $\mathrm{H} 3 \mathrm{a}$ and $\mathrm{H} 3 \mathrm{~b}$, the results of regression analysis showed that $\mathrm{D}-\mathrm{W}$ statistic were 2.214 and 1.973 with a VIF of 1.000 ranging between 1.5 2.5, which implies no autocorrelation. For H3a, the determination coefficients showed that $\mathrm{R} 2=0.547$, Adj-R2 $=0.543, \mathrm{~F}=150.876$, and $\beta=0.740$ $(\mathrm{P}=0.00<0.001)$. For $\mathrm{H} 3 \mathrm{~b}$, the determination coefficients showed that $\mathrm{R} 2=0.266$, Adj-R2 $=0.270$, $\mathrm{F}=45.651$, and $\beta=0.516(\mathrm{P}=0.00<0.001) . \mathrm{H} 3 \mathrm{a}$ and $\mathrm{H} 3 \mathrm{~b}$ reached a significance level. For $\mathrm{H} 4$, the results showed that $\mathrm{D}-\mathrm{W}=2.162$ and the determination coefficients showed that $\mathrm{R} 2=0.211$, Adj$\mathrm{R} 2=0.205, \mathrm{~F}=33.521$, and $\beta=0.460(\mathrm{P}=0.00<0.001)$ reached a significance level. For H5, the results showed that $\mathrm{D}-\mathrm{W}=1.896$ and the determination coefficients showed that $\mathrm{R} 2=0.146$, Adj- 
$\mathrm{R} 2=0.139, \mathrm{~F}=21.346$, and $\beta=0.382(\mathrm{P}=0.00<0.001)$ reached a significance level. For H6, the results showed that $\mathrm{D}-\mathrm{W}=1.843$ and the determination coefficients showed that $\mathrm{R} 2=0.141$, Adj$\mathrm{R} 2=0.134, \mathrm{~F}=20.638$, and $\beta=0.375(\mathrm{P}=0.00<0.001)$ reached a significance level. Table 3 shows the results of regression analysis.

Table 3. The results of regression analysis

\begin{tabular}{|c|c|c|c|c|c|c|}
\hline & \multicolumn{2}{|c|}{ Variable } & $\mathrm{F}$ & $\beta$ & $\mathrm{t}$ & VIF \\
\hline H1a & Convenience & $\begin{array}{c}\text { Perceived } \\
\text { Usefulness } \\
\end{array}$ & 14.999 & .327 & 3.873 & 1.000 \\
\hline \multicolumn{7}{|c|}{$\mathrm{R}^{2}=.107$, Adj $\mathrm{R}^{2}=.100, p=.000, \mathrm{D}-\mathrm{W}=1.965$} \\
\hline & \multicolumn{2}{|c|}{ Variable } & $\mathrm{F}$ & $\beta$ & $\mathrm{t}$ & VIF \\
\hline $\mathrm{H} 1 \mathrm{~b}$ & Convenience & $\begin{array}{l}\text { Perceived Ease } \\
\text { of Use }\end{array}$ & 16.824 & .343 & 4.102 & 1.000 \\
\hline \multicolumn{7}{|c|}{$\mathrm{R}^{2}=.118, \mathrm{Adj} \mathrm{R}^{2}=.111, p=.000, \mathrm{D}-\mathrm{W}=1.978$} \\
\hline & \multicolumn{2}{|c|}{ Variable } & F & $\beta$ & $\mathrm{t}$ & VIF \\
\hline $\mathrm{H} 2 \mathrm{a}$ & Compatibility & $\begin{array}{c}\text { Perceived } \\
\text { Usefulness }\end{array}$ & 64.112 & .582 & 8.007 & 1.000 \\
\hline \multicolumn{7}{|c|}{$\mathrm{R}^{2}=.339$, Adj $\mathrm{R}^{2}=.334, p=.000, \mathrm{D}-\mathrm{W}=2.296$} \\
\hline & \multicolumn{2}{|c|}{ Variable } & $\mathrm{F}$ & $\beta$ & $\mathrm{t}$ & VIF \\
\hline $\mathrm{H} 2 \mathrm{~b}$ & Compatibility & $\begin{array}{l}\text { Perceived Ease } \\
\text { of Use }\end{array}$ & 25.126 & .408 & 5.013 & 1.000 \\
\hline \multicolumn{7}{|c|}{$\mathrm{R}^{2}=.166$, Adj R $\mathrm{R}^{2}=.160, p=.000, \mathrm{D}-\mathrm{W}=1.977$} \\
\hline & \multicolumn{2}{|c|}{ Variable } & F & $\beta$ & $\mathrm{t}$ & VIF \\
\hline Hза & Trust & $\begin{array}{c}\text { Perceived } \\
\text { Usefulness } \\
\end{array}$ & 150.876 & .740 & 12.283 & 1.000 \\
\hline \multicolumn{7}{|c|}{$\mathrm{R}^{2}=.547$, Adj $\mathrm{R}^{2}=.543, p=.000, \mathrm{D}-\mathrm{W}=2.214$} \\
\hline & \multicolumn{2}{|c|}{ Variable } & $\mathrm{F}$ & $\beta$ & $\mathrm{t}$ & VIF \\
\hline $\mathrm{H} 3 \mathrm{~b}$ & Trust & $\begin{array}{l}\text { Perceived Ease } \\
\text { of Use }\end{array}$ & 45.651 & .516 & 6.757 & 1.000 \\
\hline \multicolumn{7}{|c|}{$\mathrm{R}^{2}=.266$, Adj $\mathrm{R}^{2}=.270, p=.000, \mathrm{D}-\mathrm{W}=1.973$} \\
\hline & \multicolumn{2}{|c|}{ Variable } & $\mathrm{F}$ & $\beta$ & $\mathrm{t}$ & VIF \\
\hline H4 & $\begin{array}{c}\text { Perceived Ease } \\
\text { of Use }\end{array}$ & $\begin{array}{c}\text { Perceived } \\
\text { Usefulness }\end{array}$ & 33.521 & .460 & 5.790 & 1.000 \\
\hline \multicolumn{7}{|c|}{$\mathrm{R}^{2}=.211, \mathrm{Adj} \mathrm{R}^{2}=.205, p=.000, \mathrm{D}-\mathrm{W}=2.162$} \\
\hline & \multicolumn{2}{|c|}{ Variable } & $\mathrm{F}$ & $\beta$ & $\mathrm{t}$ & VIF \\
\hline H5 & $\begin{array}{l}\text { Perceived } \\
\text { Usefulness } \\
\end{array}$ & Satisfaction & 21.346 & .382 & 4.620 & 1.000 \\
\hline \multicolumn{7}{|c|}{$\mathrm{R}^{2}=.146, \mathrm{Adj}^{2}=.139, p=.000, \mathrm{D}-\mathrm{W}=1.896$} \\
\hline & \multicolumn{2}{|c|}{ Variable } & $\mathrm{F}$ & $\beta$ & $\mathrm{t}$ & VIF \\
\hline H6 & $\begin{array}{c}\text { Perceived Ease } \\
\text { of Use }\end{array}$ & Satisfaction & 20.638 & .375 & 4.543 & 1.000 \\
\hline \multicolumn{7}{|c|}{$\mathrm{R}^{2}=.141, \operatorname{Adj} \mathrm{R}^{2}=.134, p=.000, \mathrm{D}-\mathrm{W}=1.843$} \\
\hline
\end{tabular}

\section{Conclusion}

The results of this research can provide a reference for corporate development and mobile payment promotion. This study finds that convenience has a significant effect on the perceived usefulness and perceived ease of use of mobile payment. Through Pearson's correlation coefficient analysis and regression analysis, the results demonstrate a very significant effect. In other words, the user's perception of the convenience of mobile payment is high, the higher the perceived usefulness and perceived ease of use. Furthermore, the compatibility of mobile payment has a significant effect on perceived usefulness and perceived ease of use. Through Pearson's correlation coefficient analysis and regression analysis, the results show a significant effect. The user's recognition of the compatibility of mobile payment is high, the higher the perceived usefulness and perceived ease of use. This study finds that trust has a significant effect on the perceived usefulness and perceived ease of use of mobile payment. Through Pearson's correlation coefficient analysis and regression analysis, the results show a very significant effect. The use's perception of the trustworthiness of mobile payment is high, the higher the perceived usefulness and perceived ease of use. 
The study results showed that perceived ease of use has a significant effect on perceived usefulness. The study results also finds that the user's perceived usefulness and user-friendliness have a significant effect on his or her satisfaction with mobile payment. Through Pearson's correlation coefficient analysis and regression analysis, the results show a very significant effect. In other words, the higher the degree of the user's perception of the usefulness and perceived ease of use of mobile payment, the higher his or her degree of satisfaction.

\subsection{RECOMMENDATION OF ThIS STUDY}

Because most users still are not accustomed to or familiar with mobile payment in comparison to payment using actual banknotes, it is not possible for all stores to adopt mobile payment checkout. For this reason, it is recommended that businesses should actively move towards mobile payment, so that users can use mobile payment anytime anywhere. As users use mobile payment more often, they will naturally become familiar with it. Businesses can also improve mobile payment based on feedback provided by users. While most users think that the overall process of using mobile payment is safe and secure, there are still users who experience mobile payment failure during the operation and suffer a loss of personal money. This causes users to lose confidence in mobile payment and shy away from using it again. Therefore, businesses must actively develop mobile payment to ensure that mistakes do not occur.

\subsection{LiMitATION AND FUTURE DiRECTIONS}

In the overall research process, this study has experienced some difficulties and limitation in relation to research resources and time, so some suggestions are given here for future scholars and businesses to follow up on. Future researchers may consider setting the subjects to different specific groups and distributing the average proportion in order to understand the different needs that different groups have on mobile payment and to explore which age group has the highest number of mobile payment users. This will provide a more accurate reference for businesses to develop and market. In addition, it is recommended that future researchers should take further steps to validate both the quantitative and qualitative research methods and to explore relevant literature or theory and incorporate other possible factors into their studies.

\section{ACKNOWLEDGEMENTS}

The authors would like to thank the National Science Council of Taiwan for financial support (NSC103-2815-C-214-001-H). The authors would also like to thank the editors and anonymous reviewers for their generous comments and suggestions.

\section{REFERENCES}

[1] Lu, H. P. and Su, Y. J. (2009). "Factors affecting purchase intention on mobile shopping web sites," Internet Research, Vol.19, No. 4, pp. 442-458.

[2] Zhang, R., Chen, J. Q., and Lee, C. J. (2013). "Mobile commerce and consumer privacy concerns," The Journal of Computer Information Systems, Vol. 53, No. 4, pp. 31-38.

[3] Kim, C., Mirusmonov, M., and Lee, I. (2010). "An empirical examination of factors influencing the intention to use mobile payment," Journal Computers in Human Behavior, Vol. 26, No. 3, pp. 310322.

[4] Nguyen, N., Cao, T. K., Dang, P. L. and Nguyen, H. A. (2016). "Predicting consumer intention to use mobile payment services: empirical evidence from Vietnam," International Journal of Marketing Studies, Vol. 8, No. 1, pp. 117-124.

[5] Pousttchi, K. and Wiedemann, D. G. (2007). "What influences consumers' intention to use mobile payments?"

Retrieved

from: 
https://pdfs.semanticscholar.org/a4dd/ce87edaa6d2bf14d0bd362e1c9beb24b030b.pdf (March, 22, 2017).

[6] Ondrus, J. and Pigneur, Y. (2007). "Cross-industry preferences for development of mobile payments in Switzerland,” Electronic Markets, pp. 142-152.

[7] Liébana-Cabanillas, F., Ramos de Luna, I., and Montoro-Ríos, F. (2017). "Intention to use new mobile payment systems: a comparative analysis of SMS and NFC payments," Economic ResearchEkonomska Istraživanja, Vol. 30, No. 1, pp. 892-910.

[8] Dornan, A. (2001). "The essential guide to wireless communications applications: from cellular systems to WAP and m-commerce," Upper Saddle River, NJ, Prentice Hall.

[9] Heijden, H. (2002). "Factors affecting the successful introduction of mobile payment systems," 15th Bled Electronic Commerce Conference eReality: Constructing the eEconomy, Bled, Slovenia, June 17-19, pp. 430-443.

[10] Hahn I. and Kodó, K. (2017). “Mobile payment analysed from the aspects of Kano model.” Retrieved from: http://www.diva-portal.org/smash/get/diva2:1079862/FULLTEXT01.pdf (March, 22, 2017).

[11] Dahlberg, T., Mallat, N., Ondrus, J., and Zmijewska, A. (2008). "Past, present and future of mobile payments research: a literature review," Electronic Commerce Research and Applications, Vol. 7, No. 2, pp. $165-181$.

[12] Varshney, U. (2002). “Mobile payment," IEEE Computer, Vol. 35, No. 12, pp. 120-121.

[13] Ondrus, J. and Pigneur, Y. (2006). "Towards a holistic analysis of mobile payments: a multiple perspectives approach," Electronic Commerce Research and Applications, Vol. 5, No. 3, pp. 246-257.

[14] Sang, R. J. and Murdock, K. (2013). "Consumer acceptance of mobile marketing communications using the QR code," Journal of Direct, Data and Digital Marketing Practice, Vol. 15, No. 2, pp. 11124.

[15] Davis, F. D. (1989). "Perceived usefulness, perceived ease of use, and user acceptance of information technology,” MIS Quarterly, Vol. 13, No. 3, pp. 319-340.

[16] Fishbein, M. and Ajzen, I. (1975). "Belief, attitude, intention, and behavior: an introduction to theory and research". Reading, MA: Addison-Wesley.

[17] Taylor, S. and Todd, P. (1995). “Assessing IT usage: the role of prior experience," MIS Quarterly, Vol. 19, No. 4, pp. 561-570.

[18] Gefen, D., Karahanna, E., and Straub, D. W. (2003), "Trust and TAM in online shopping: an integrated model," MIS Quarterly, Vol. 27, No. 1, pp. 51-90.

[19] Moon, J.W. and Kim, Y.G. (2001). "Extending the TAM for a world-wide-web context," Information \& Management, Vol. 38, pp. 217-230.

[20] Venkatesh, V. and Davis, F. (2000). "A theoretical extension of the technology acceptance model: four longitudinal field studies,” Management Science, Vol. 46, No. 2, pp.186-204.

[21] Brown, L. G. (1989). "The strategic and tactical implications of convenience in consumer product marketing," The Journal of Consumer Marketing, Vol. 6, No. 3, pp. 13-19.

[22] Yoon, C. and Kim, S. (2007). "Convenience and TAM in a ubiquitous computing environment: the case of wireless LAN," Electronic Commerce Research \& Applications, Vol. 6, No. 1, pp. 102-112.

[23] Rogers, E.M. (2003). Diffusion of innovations (5th ed.). New York: Free Press.

[24] Craig, V.S., France, B., and Christie, L.C. (2004), "Factors influencing the adoption of web based shopping: the impact of trust," ACM SIGMIS Database, Vol. 35, No. 2, pp. 32-49.

[25] Kim, E. and Tadisina, S. (2007). "A model of customers' trust in e-businesses: Micro-level inter-party trust formation,” Journal of Computer Information Systems, Vol. 48, No. 1, pp. 88-104.

[26] Kalakota, R. and Whinston, A. B. (1996). "Readings in Electronic Commerce" Addison-Wesley Publishing, Reading, MA.

[27] Yoon, S. J. (2002). "The antecedents and consequences of trust in online-purchase decisions," Journal of Interactive Marketing, Vol. 16, No. 2, pp. 47-63.

[28] Dahlberg, T., Mallat, N., and Öörni, A. (2003). Trust enhanced technology acceptance modelconsumer acceptance of mobile payment solutions: Tentative evidence, Stockholm Mobility Roundtable, 22-23.

[29] Nunnally, J. C. (1978). "Psychometric theory," New York: McGraw-Hill. 